\title{
Jan Stepan \\ 1914-2002
}

Jan Stepan, a native of Bohemia, was born in 1914 in what is now the Czech Republic, and he died in that country in 2002. During his lifetime, he had several distinguished careers: first, in his native country as a lawyer, law teacher and scholar; then, in the United States as the international law librarian at the Harvard Law School; and, finally in Switzerland as Librarian and Vice Director of the Swiss Institute of Comparative Law in Lausanne. Beyond these basic facts, Jan Stepan was a man of great moral and intellectual stature. He was a Czech hero in his defense of civil liberties, and a librarian whose knowledge of international and comparative law enriched the collections and readers of two great law libraries. Relatively late in life, at the age of fifty-six, Jan Stepan became a law librarian by a fortunate coincidence which occurred at a tragic moment in his country's history. His devotion to law librarianship stemmed not only from his love of legal scholarship and of teaching, but also from the fact that it was for him a life-saving career.

Jan Stepan received the degree of doctor of jurisprudence from Charles University, Prague, in 1938, and then practiced law in Prague from 1938 to 1963. He was a lecturer in law at his alma mater from 1963 to 1968, specializing in criminal law and medical jurisprudence. During those years he published fifteen articles in Czech or French on criminal law; three on medical jurisprudence; one monograph on criminal investigation and two monographs on law and medicine (one of those with his brother, Jaromir Stepan, a physician). In the 1960's, when there was growing unrest in Czechoslovakia and resistance to the Communist regime, Dr. Stepan was known for his liberal views and his defense of civil liberties. Later, in the Prague Spring of 1968, popular discontent forced a change in the government and an opening of that repressed society, which occurred under the leadership of Alexander Dubcek. Stepan was an important voice for change during those exciting days. When I visited Prague in the 1972 after Soviet troops had invaded Czechoslovakia 
and repressive rule had been reimposed, I was told by young lawyers that Stepan had been their hero and an influential proponent of reform at Charles University and in the Czech legal profession.

At the time of the Soviet invasion in August 1968, Jan Stepan was participating in the Salzburg Summer Seminar in Austria. When news of those tragic events reached him, Stepan realized that it would be dangerous for him to return to Prague. By chance, Professor Louis Loss of the Harvard Law School was attending the Salzburg Seminar that summer and he began arrangements for Stepan and his wife, Hana, who was a dentist, to emigrate to the United States. They spent the year 1968-69 in Salzburg on a grant to Jan to do research at the University of Salzburg. When they arrived in America in 1969, he was appointed a reference librarian in the Harvard Law School Library. In 1975, he became Assistant Librarian for Foreign and International Law, a position he held until his retirement in 1983. Jan and Hana Stepan became United States citizens in 1975.

I came to the Harvard Law School as its Librarian in 1971 and had the pleasure of serving with Jan Stepan for ten years. I knew him as a superb bibliographic scholar of international and comparative law and medical jurisprudence. He was a service-oriented librarian devoted to the needs of faculty and students. Although by necessity he initially deferred his own scholarly interests, he kept up with developments in criminal law and medical jurisprudence and even enlarged his focus to the comparative and international dimensions of those fields. He continued to publish extensively in Czech, English, French and German, in the fields of his interest, including law librarianship. He contributed several pieces to this Journal.

While we were together at Harvard, Jan Stepan and I collaborated on at least six publications. I knew him to be a congenial and generous colleague, who brought new insights to my own work and to the work of others at Harvard and beyond. During the year 1978-79, we worked together with Naomi Ronen of the Harvard Law School Library staff on a pioneering bibliography on law and science which, after several revisions, was published as a book by the M.I.T. Press. ${ }^{1}$ In that same year, Stepan also became a member of a newly established international legal commission on voluntary sterilization and delivered papers on voluntary sterilization to the World Congress of Medical Law in Ghent and the $4^{\text {th }}$ International Conference on

${ }^{1}$ Law \& Science: A Selected Bibliography (M.I.T. Press, 1980). 
Voluntary Sterilization in Seoul, South Korea. His $100^{\text {th }}$ publication was issued in that same year.

One of our major collaborations was a series of classification schemes for the World Health Organization (WHO), with Dr. Luke T. Lee of Tufts University. In the course of this work, we had occasion to travel to the WHO in Geneva and meet with officials of that organization. I was impressed by the wisdom Dr. Stepan brought to our discussions and how effective he was in editorial negotiation. While at Harvard, he was also involved in the founding of the Annual Review of Population Law. He contributed selective bibliographies of publications on law and population to that annual volume from 1980 to 1989.

Terry Martin, Librarian of the Harvard Law School, in his announcement of Jan Stepan's death, summarized Stepan's years at Harvard, as follows:

At Harvard Jan was noted for his breadth of knowledge, his unstinting efforts at expanding the foreign law collections, and the mentoring of young comparativists. Outside the Law School, Jan poured the energy of a man twenty years younger into efforts to convince Americans that the death penalty was wrong and uncivilized. A man of immense Old-World charm, he developed a deep expertise in cutting-edge issues in law and medicine, particularly how new technologies began to affect reproductive rights... Jan Stepan made significant contributions to three professions on two continents. A lawyer, scholar, and librarian, he was, above all, a gentleman. He leaves a long list of publications, but a longer list of friends.

Stepan's interest in classification continued when he moved to Switzerland in 1981 to become Librarian and Vice Director of the newly created Swiss Institute of Comparative law. As the founding Librarian of that important Institute, he not only built a fine collection from scratch and developed an outstanding staff, but also designed and installed a new law classification for foreign, comparative and international law. ${ }^{2}$

2 "A new classification of law for a foreign, comparative, and international research law library: the system of the Swiss Institute of Comparative Law", 16 Vanderbilt 
In 1986, Dr. Stepan retired from his positions at the Swiss Institute of Comparative Law. He continued to be an active presence at the Institute after his retirement. It is significant that the three individuals who were to be his successors there, had been among his many proteges in law librarianship: Holger Knudsen, Fred Chapman, and Jarmila Looks. In 1995, Jan and Hana Stepan returned to Czechoslovakia to be near their children and many grandchildren and great-grandchildren.

On his $80^{\text {th }}$ birthday, Jan Stepan was honored by his colleagues from all over the world with a festschrift containing thirty articles in four different languages. ${ }^{3}$ In their preface, the editors, Jarmila Looks and Fred Chapman noted: "Since his fifty-fifth birthday, [Jan Stepan] has learned a new profession, acquired an international reputation as an authority in the law of reproductive medicine, created a remarkable foreign law library from empty shelves - and added more than seventy items to the already long list of his publications."

Jan Stepan will be remembered by the many people whose lives he touched and by many more who knew him only from a distance. He was a beloved colleague and friend to a world of law librarians, and was truly a man for all seasons. His tomb in Podebrady, Czech Republic, which was designed by one of his grandsons, describes him simply as Jan Stepan, Gentleman of Law. That is indeed a very appropriate description!

\author{
Morris L. Cohen \\ Law Librarian (Retired) \\ Emeritus Professor of Law \\ Yale Law School \\ New Haven, Connecticut, USA
}

The author of these lines had the immense luck and privilege of meeting Jan Stepan shortly after his arrival in Lausanne, and of working for him for over 10 years at the Swiss Institute of Comparative Law.

\footnotetext{
Journal of Transnational Law (1983) pp. 557-582.

${ }^{3}$ Festschrift fur Jan Stepan/ Melanges en l'honneur de Jan Stepan/ Essays in Honour of Jan Stepan (Zurich: Schulthess Polygraphischer Verlag, 1994).
} 
At an age when other people think of retiring, Jan came to Switzerland, not to work peacefully in a quiet little place on the Lake Geneva, but to start something completely new, to create what is now one of the major international and comparative law libraries in Europe.

Alfred von Overbeck, then director of the newly born Institute, recalls the hiring of the Librarian in $1980^{4}$ : Many candidates invited to Lausanne for an interview ended up backing out, because of the amount of work linked with the task, or because of a salary, considered too modest. There was one application left, that of Jan Stepan, at the time Assistant Librarian for Foreign and International Law at Harvard. Would a man of 66 years of age be able to create a library out of a couple of boxes, a provisory office and a building under construction? In spite of the initial skepticism, Professor von Overbeck flew over to Harvard to meet with him. The two men liked each other immediately, and Jan accepted the new job without any hesitation.

Jan put an incredible amount of energy into his new assignment. In the first place, he contributed essential ideas to the creation of the new building. In addition, he hired an excellent staff of librarians, many of whom are still working at the Institute. Together with his team, he acquired legal literature from all over the world, bringing into existence an outstanding and well chosen collection of research material in an incredibly short time, a collection classified according to a scheme specifically designed for the Institute by a group of experts under Jan's chairmanship. ${ }^{5}$

One might be inclined to believe, that a man of such enormous efficiency would perhaps not be sensitive to people around him. This certainly was not the case with Jan. Always carefully listening to others and never losing interest in other people's lives, he remained humble despite his vast knowledge and experience. The nobility of his character and mind were of rare dimensions and constancy. Jan always considered himself extremely fortunate and made it a life long duty to share his wealth with others, especially with the vulnerable ones. A terrible event resulting in the death of a young woman at the very beginning of his career as a practicing lawyer in the Czech

\footnotetext{
${ }^{4}$ Alfred E. von Overbeck, "Hommage à Jan Stepan" in Festschrift für Jan Stepan zum 80. Geburtstag, ed. by Jarmila Bednarikova [Looks] \& Frank C. Chapman, II, Zurich, 1994, pp. 1-5.

${ }^{5}$ For more detail concerning the classification, see the contribution by Morris Cohen, supra.
} 
Republic affected him deeply and made Jan into a passionate defender of women's rights through all of his life. An outstanding criminal law and procedure specialist, he was above all engaged in the defense of human rights - among his numerous clients were members of the Roma minority, generally considered suspects in all sorts of crimes and misdemeanors. His stay in America whose people he genuinely loved involved, among other activities, an effort devoted to combating the death penalty, a stain he was never ready to forgive the nation worshiping liberty.

Jan's generosity also found its expression in his relations with peers and colleagues. Unselfishly assisting in their research, he remained in touch with them whenever he came upon any kind of information that might be of interest to them. Countless are the careers and scientific and legislative activities that he did influence this way. During the entire period of exile in the United States and in Switzerland, he continuously made efforts to supply the library of the Law School in Prague with otherwise unobtainable foreign literature. Back home, at an age of more than 80 , he was an esteemed consultant to the Czech Bar Association, to the Ministry of Justice and to the Supreme Court. In 1992 the Czech Unity of Lawyers, in recognition of his merits, awarded him the prestigious Medal of Antonin Randa. ${ }^{6}$ A few years later, in 1998, he was awarded the Jubilee $\mathrm{Medal}^{7}$ for his contribution to the development of legal science and culture by the Charles University in Prague.

Jan could have been proud of all his achievements, yet he was always a modest man. Retired in a small town outside Prague, he continued to contribute in an essential but discreet way to the legislative reforms taking place in his country of origin. He published a number of scholarly articles mostly in the field of criminal procedure, co-operated with the Faculty of Law in Prague, and co-authored a textbook on criminal procedure. Jan contributed the chapters on the protection of civil rights and liberties and on the principles of Anglo-American criminal procedure. In addition, he published a series of articles for leading Czech newspapers.

${ }^{6}$ In appreciation of the work of prominent lawyers, the Unity awards the Randa Medal. This highly prestigious award has been bestowed on judges, solicitors, and scientists. The medal is presented in the Carolinum, the ancient hall of Charles University. More about Antonin Randa and the Union at http://www.mpo.cz/gc/0797/ page0010.htm.

${ }^{7}$ In 1998 the Charles University, Prague, celebrated the 650th anniversary of its founding. 
Jan Stepan was a loving husband, father, grandfather and greatgrandfather. Deeply devoted to his wife Hana, he never forgot that she followed him, sacrificing her own professional career, and he surrounded her with care and love until his very last day.

A deeply moved crowd gathered at his funeral in Podebrady: his large family, numerous colleagues, neighbors, and friends - anonymous and not so anonymous. We all shared a time of immense sadness, but also the privilege and gratitude of having experienced the truly exceptional grandeur that Jan possessed. May his memory never fade.

Jarmila Looks

Vice-Director, Head of the Library Swiss Institute of Comparative Law Lausanne, Switzerland

Jarmila Looks and Morris Cohen have written eloquent tributes to the life, multifaceted career, and contributions to legal scholarship of the late Jan Stepan. Before briefly describing his important contributions to the work of the World Health Organization (WHO), let me quote the reactions I received from two eminent scholars to whom I had the sad duty of conveying the news of Jan's death:

He was a tremendous support and inspiration to me in my work, especially during my law school days. He lived with great dignity and treated people with dignity" (from a Professor of International Human Rights Law, based in Canada).

He was so staunch on reproductive health and reproductive rights, such a fine researcher, such a learned man....It's important for young lawyers to know of such a rich tradition. How dedicated he was. How helpful he was to everyone working in the field. How gracious, how principled. And what hard times he lived through...." (from a Professor of Heath Law, based in the USA). 
Professor Cohen has alluded to the important work that Jan and he undertook at the request of WHO, and specifically the complex task of restructuring one of the Organization's journals, the International Digest of Health Legislation. Since its creation in 1948 as the successor to the section on laws and regulations contained in the Bulletin de l'Office International d'Hygiène publique, legislative materials had been classified exclusively according to country or subnational jurisdiction of origin. An exhaustive inquiry conducted in 1978 and 1979, with the substantial and substantive help of specialists from Harvard, UCLA, and Egypt, in response to a World Health Assembly Resolution of May 1977, had indicated that most users at the country level favored classification by subject. Cohen and Stepan jointly produced such a classification, with legislative materials grouped into 22 sections. Their classification scheme has stood the test of time and has been essentially retained in the online version of the journal, which replaced the printed version a few years ago.

During his years at Harvard and Lausanne, Stepan not only was able to retrieve difficult-to-find legislative texts as well as books and monographs on health and medical law and cognate subjects, but was also a constant source of encouragement and creative ideas. One of his notable contributions was a comparative survey of legislation on traditional and other forms of "alternative" or "complementary" medicine, published in the Digest in 1985.

It should be mentioned en passant that $W H O$ was able to assist the Lausanne Institute from time to time. For example, under Stepan's direction, a two-volume study on ethical and legal problems at the beginning and end of life had been prepared in the early 1980s, with modest input from what was then WHO's Health Legislation Unit. The study had been commissioned by the Swiss Federal Department of Justice and Police. Wandering around the already impressive stacks of the Institute's Library on the occasion of the Institute's formal opening in 1982, the writer of these lines chanced upon Stepan accompanied by Mr. Kurt Fürgler, the distinguished Federal Councillor, then Head of that Department. With his paradigmatic courtesy, Stepan introduced me to Mr. Fürgler, and added that I had been a member of the WHO group that had aided the Institute in the preparation of the monograph.

Stepan played a significant role in the World Association for Medical Law and he, in particular, contributed to the organization of a highly successful Congress of that body held in Prague in the summer of 1988. The conference took place not long before the Velvet Revolution that was to transform the then 
ČSSR and twenty years after the Prague Spring, an event that, as Cohen describes,-was to internationalize Stepan's already brilliant career.

I sometimes wondered if Jan would ever retire and relax. Retire he did, but he remained very active in the years preceding his death. I am aware that he worked with Reed Boland until quite recently in the preparation of the Annual Review of Population Law, jointly produced by Harvard Law School and the United Nations Population Fund (UNFPA) - an invaluable source of information for academics and others (and they are many) interested in that field. I always read his Christmas letters with great interest - detailed accounts of what he had written and what was in the pipeline, but never a word of the honors he was receiving in the Czech Republic and of which I learned only by reading Jarmila Looks' In Memoriam.

Jan Stepan was a scholar and a gentleman, who will be sorely missed by a host of colleagues, admirers and friends, who benefitted enormously from his wisdom and learning, who appreciated his very Old World courtesy, kindness, and modesty, and who valued his willingness to be of assistance to all who sought his counsel.

Sev Fluss

Special Adviser to the Secretary-General of the Council for International Organizations of Medical Sciences clo World Health Organization

Geneva, Switzerland 